\title{
Motivating Capital Investment by Using the Audit Process to Increase Financial Transparency
}

\author{
J. Reid Cummings, D.B.A. (Corresponding Author) \\ University of South Alabama \\ 5811 USA South Drive, MCOB 126, Mobile, Alabama 36688 \\ E-mail: cummings@southalabama.edu
}

Gabriel G. Ramirez, Ph.D.

Kennesaw State University

Divesh S. Sharma, Ph.D.

Kennesaw State University

Kyre D. Lahtinen, Ph.D.

University of South Alabama

Received: Sep. 5, 2017 Accepted: March 10, $2018 \quad$ Published: June 1, 2018

doi:10.5296/ajfa.v10i1.11810 URL: https://doi.org/10.5296/ajfa.v10i1.11810

\begin{abstract}
This study examines the relationship between REITs' uses of the audit process to increase financial transparency, and their ability to attract and/or maintain reasonable access to capital investment. We find that capital investment is positively and significantly associated with auditor quality, specialization, and reputation. After controlling for the effects of the 2007-2008 financial crisis, we find that when REITs seek to attract new capital investment, using the audit process to increase financial transparency is just as important before the crisis as after it. These findings suggest that regardless of the economic conditions, auditor quality, specialization, and reputation add value.
\end{abstract}

Keywords: Real Estate Investment Trusts, financial transparency, auditor quality, auditor specialization, auditor reputation, capital investment 


\section{Introduction}

United States federal law requires Real Estate Investment Trusts (REITs) to distribute at least $90 \%$ of their net income to shareholders as dividends (Scherrer, 2004). The resulting reduced cash flow constraint propels REITs to access capital markets frequently. Historically, REITs' have successfully done so, possibly due to investors' views that REITs present a safe way to invest in real estate (Goebel \& Kim, 1989; Goodman, 2000, 2003).(Note 1) As lingering economic uncertainties hampered financial markets after the 2007-2008 financial crisis, raising new capital proved challenging for many firms. Even though during the post-crisis period REITs continued to offer attractive investment opportunities,(Note 2) because many post-crisis real estate markets were in decline, attracting investors was challenging (Basse, Friedrich, \& Bea, 2009). Therefore, because of the need for new capital, it was important that REITs pursue strategies that worked to increase financial transparency so they could motivate new capital investment.

The complexity of a firm's capital structure decisions often increases because of information asymmetries between firm managers and potential investors (Myers, 1984; Titman \& Wessels, 1988). By decreasing information asymmetries, firms can increase their financial transparency; when they do so successfully, they are more likely to motivate new capital investment (Beatty, 1989; Carter \& Manaster, 1990). In the course of seeking new capital, the offering prospectus is a tool firms use to send signals of increased financial transparency to potential investors and lenders. By including information beyond that which is required by regulators, firms can reveal additional information about their intrinsic value, investment grade, and future prospects (Deeds, Decarolis, and Coombs, 1997).

By revealing extensive, detailed information about their auditor, and audit process, firms can effectively decrease information asymmetries and send signals about their increased financial transparency (Danielsen, Van Ness, \& Warr, 2007; Danielsen, Harrison, Van Ness, \& Warr, 2009, 2014; Datar, Feltham, \& Hughes, 1991; Feltham, Hughes, \& Simunic, 1991; Titman \& Trueman, 1986). For example, research shows that firms hire higher quality auditors, and often pay much higher audit fees to signal investors that their financial information is highly credible (Datar, Feltham, \& Hughes, 1991; Titman \& Trueman, 1986). Because investors interpret the signal to mean the auditor will be less likely to yield to management pressures to withhold or obfuscate negative information, they often view the firm as being more financially transparent. Thus, in a sense, the firm is relying on the reputational capital of the higher quality, more expensive auditor to signal investors that they are more financially transparent (Feltham, Hughes, \& Simunic, 1991). If firms can successfully use the audit process to convey increased financial transparency, in doing so, logic dictates expectations of heightened access to capital investment. Thus far, however, there has been no examination of whether increased transparency via the auditing process leads to better access to capital markets, or more importantly, whether it does so during periods of high capital market illiquidity caused by major financial system shocks.

In this study, we examine the connection between REITs' uses of the audit-related attributes of auditor quality, auditor specialization, and auditor reputation to signal increased financial 
transparency, and REITs' access to capital investment. This is an important issue because as REITs must frequently access capital markets, they need strategies that enhance their efforts to motivate investment. Moreover, for REITs, this issue takes on added significance when volatile financial market conditions make accessing capital difficult. Overall, we find that capital investment is positively and significantly associated with three commonly used audit-related attributes: auditor quality (captured by higher audit fees), auditor specialization (captured by industry-audit specialization), and auditor reputation (captured by the audit firm being a Big 4 auditor). After controlling for the effects of the financial crisis, we find that when REITs seek to attract new capital investment, using the audit process to increase financial transparency is just as important before the crisis as after it.

The remainder of this paper proceeds as follows. The next section discusses existing research supporting using the audit process to convey increased financial transparency to investors. The third section presents hypotheses development. The fourth section describes dataset construction. The fifth section outlines the study's research design and methodology. The sixth section presents results and analysis discussion. The last section offers concluding remarks.

\section{Literature Review}

We base our examination on a wide-ranging, well-developed body of academic literature. Drawing on economics, signaling theory provides the foundation for our study. Guided by the finance literature, we include often-used measures to capture financial transparency, and information asymmetry and opacity. Following the auditing and accounting literature, we use three audit-related attributes to proxy for REITs' efforts to increase transparency. Finally, we take into account multiple REIT-related regulatory, structural, investment, and operational characteristics rooted in the real estate literature.

\subsection{Information Asymmetry, Financial Transparency Signaling, Liquidity, and the Audit Process}

Although providing financial information can reduce information asymmetries between firms and prospective investors and lenders, to be effective, it must also be transparent (Bushman \& Smith, 2001, 2003; Diamond \& Verrecchia, 1991; Fama \& Jensen, 1983). To view financial information as transparent, the receiver must believe that both the information itself and its sender are credible (Spence, 1973). Financial transparency is important to investors, and researchers show that firms successfully increase their liquidity by becoming more financially transparent when seeking new capital investment (Cohen, Krishnamoorthy, \& Wright, 2002; Danielsen et al., 2014; Karamanou \& Vafeas, 2005). Francis, Lys, and Vincent (2004) find that REITs typically experience more favorable investor reaction than other types of firms when issuing securities, and that signaling plays a significant role in the way investors react to such offerings. Hence, signaling is important to firms seeking to reduce information asymmetries and increase financial transparency because doing so enhances their abilities to attract investment. For firms such as REITs that must access capital often to maintain their liquidity, successfully signaling financial transparency can often prove to be critical. 
When raising capital, firms can use the audit process to signal investors about their reduced information asymmetry and increased financial transparency (Healy \& Palepu, 2001). Firms can signal their financial transparency, and by extension, their credibility, by providing highly accurate and reliable audited financial statements (Hope, Thomas, \& Vyas, 2009). To be credible, signals must be costly and difficult to replicate (Spence, 1973). Three audit process attributes investors use to evaluate a firm's financial transparency are hiring high quality auditors (costs associated with higher audit fees), audit industry specialists (costs associated with industry audit specialization), and audit firms with superior reputations (costs associated with Big 4 audit firm status) (Datar et al., 1991; Titman \& Trueman, 1986).

\subsection{Financial Transparency and Auditor Quality}

Numerous studies use audit fees to signal financial transparency. Danielsen et al. (2009) examine which firms are most likely to benefit from a higher priced audit. They find that firms that signal greater financial transparency through heavier investment in audit services reduce their capital costs when offering seasoned equity issues. Beatty (1989) finds that firms who pay a premium for audit services have lower initial returns after going public, which suggests that firms willing to pay more for audit services do so to send investors signals of increased financial transparency. Higgs and Skantz (2006) conclude that investors interpret high audit fees as signals of a firm's commitment to high earnings quality. Hay and Davis (2002) find that firms seeking higher quality audits do so for signaling reasons. Peel and Roberts (2003) find that small firms willingly hire higher priced audit firms to send signals of operations and earnings quality to investors. Danielson et al., (2009), suggest that because REITs can derive benefits from hiring high quality auditors, doing so to convey financial transparency can be an important aspect of REITs' capital structure mechanisms. It seems logical, therefore, that if using vigorous audit services "can improve liquidity for any firm, it seems especially likely to do so for REITs” (Danielsen et al., 2009, p. 517).

\subsection{Financial Transparency and Auditor Specialization}

REIT audits are complex, partly because they operate in a highly regulated environment, and partly because the majority of their assets are valuation driven. Equity REITs hold independent, self-contained property investments, each with their own sources and uses of funds, and each with their own varying degrees of risk. These may be difficult for the auditor to understand or value (Danielsen et al., 2009; Friday \& Sirmans, 1998). Because mortgage REITs hold myriad commercial mortgage-backed securities, real estate mortgage notes, and other types of real estate credit facilities, without a thorough understanding of the specific risks associated with each instrument within the portfolio, auditing a mortgage REIT might prove difficult.

REITs can signal investors about their efforts to increase financial transparency by hiring REIT industry-audit specialists. Hiring an auditor with industry specialization is likely to play an important role in conveying financial transparency to the markets, especially when the auditee presents a complex audit (Abdolmohammadi, Searfoss, \& Shanteau, 2004). Choosing to specialize in a particular industry is not a decision that audit firms take lightly, as doing so requires committing substantial amounts of time and money to train audit personnel on the 
workings of a particular industry (Lim \& Tan, 2010). Because of the auditor's advanced knowledge about the specific nature of an auditee's industry, it is less likely its managers will deceive or mislead the auditor (Solomon, Shields, \& Whittington, 1999). Equally important is that precisely because of the audit firm's industry specialization, safeguarding its reputational capital is also an important incentive for the auditor to perform quality audits (Watts \& Zimmerman, 1983). Investors understand industry-audit specialists have more to lose. Because they value the significance of an audit firm's commitment to becoming an industry specialist, they also realize that firms often hire industry-audit specialists to improve their disclosures (Dunn \& Mayhew, 2004), thereby enhancing their transparency.

\subsection{Financial Transparency and Auditor Reputation}

Auditor reputation is often associated with auditor size, because larger audit firms have more resources and can provide higher quality audits than smaller audit firms can (DeAngelo, 1981). Simunic and Stein (1987), Beatty (1989), and Chan, Ezzamel, and Gwilliam (1993) show that large audit firms charge higher audit fees than their smaller competitors because of the demand for their higher quality services, generally driven by their higher audit quality reputation. Audit firm size and reputation are also likely to convey information about the financial transparency of the auditee. Because hiring auditors with higher quality reputations is costly, firms often do so as a way of signaling increased financial transparency to investors (Titman and Trueman, 1986; Feltham et al., 1991). When firms hire auditors with higher quality reputations (such as Big 4 firms), they also benefit from the reputational quality of the audit firm (Danielson et al., 2007). When information asymmetry is high, such as when a firm is preparing to issue equity for the first time, firms are more likely to engage a larger audit firm (e.g. Big 4 auditor) to signal financial transparency. Balvers et al. (1988) and Firth and Smith (1992) find that firms experience less initial public offering underpricing when they hire larger audit firms. As investors' perceptions of higher quality auditor reputation add credibility to the audit process and enhance financial transparency, it is more likely that investors will view firms that hire auditors with higher quality reputations more favorably than those that do not.

\subsection{REITs' Capital Access and the Financial Crisis}

REITs operate in a highly regulated environment. Even the simplest of REITs are complex in structure, owning and operating their assets through a vast network of subsidiaries, partnerships, and joint venture arrangements. Because of their multifaceted nature, REITs routinely face persistent and difficult challenges of minimizing information asymmetries between themselves and investors. Financial market volatility after the crisis exacerbated these difficulties (Hardin \& Wu, 2010). Because of their frequent need for capital investment, after the crisis it was especially critical for REITs to find ways to meet and overcome these challenges. By hiring higher quality auditors, industry-audit specialists, and/or auditors with superior reputations, REITs could take steps designed to reduce information asymmetries, and, more importantly, send clear financial transparency signals to investors in order to motivate new capital investment. 


\section{Methodology}

Exogenous events such as the financial crisis can shock and disrupt capital markets. As many investors respond to such shocks by moving money from equities and corporate debt into safer investments such as government debt and cash, often the result is substantially increased capital market illiquidity. The severity of the financial crisis' shock to the financial system, and the ensuing post-crisis market conditions caused major problems for many firms needing to raise new capital. After the crisis, values in many real estate market values were declining and investors were generally shying away from real estate investments (DeLisle, 2007, 2008). Thus, for REITs, attracting new capital in such an environment was likely quite difficult.

\subsection{Hypothesis Development}

Earlier, we highlight several studies that examine the different ways firms signal financial transparency to investors to attract new capital investment. In this study, we use a two-part approach to examine the relationship between REITs' use of the audit process to signal increased financial transparency and their access to new capital. In the first part of the analysis, we examine the relationship between REITs' use of the audit process and their access to new capital, posited by the following hypothesis:

Hypothesis 1:There is a positive association between the audit process and (a) equity investment in REITs, (b) debt investment in REITs; and (c) combined equity and debt investment in REITs.

In the second part of the analysis, we examine the relationship between REITs' use of the audit process and their access to new capital, accounting for possible mediating effects of the financial crisis, posited by the following hypothesis:

Hypothesis 2: The financial crisis of 2007-2008 positively influenced the relationship between the audit process and (a) equity investment in REITs, (b) debt investment in REITs, and (c) combined equity and debt investment in REITs.

\subsection{Data Selection and Sample Construction}

After compiling a list of publicly traded REITs that operated at some point during the period 2002-2011, we reduce the sample to include only those REITs that operated in and elected REIT status for each year during the study period. (Note 3) We then review each REIT's annual report to determine the total number of subsidiaries owned or operated, and properties owned or controlled, respectively.(Note 4) We collect financial- and audit-related information from the Center for Research and Security Prices (CRSP), Compustat, and Audit Analytics databases. (Note 5) Because CRSP, Compustat, and Audit Analytics databases do not have a common identifier, we hand match all necessary REITs' financial, accounting, audit, and other firm-specific data to construct the final data sample comprised of 98 publicly traded REITs. Because 27 of the 980 firm year observations had missing items, the final dataset includes 953 firm year observations. Table 1 below lists and describes the variables used in the analysis. 
Table 1. Description of Variables

\begin{tabular}{|c|c|}
\hline Variable & Variable Description \\
\hline Log(Equity Investment) & $\begin{array}{l}\text { Natural log of (Proceeds from common and preferred stock } \\
\text { issuance }+1)^{1}\end{array}$ \\
\hline Log(Debt Investment) & Natural log of (Proceeds from debt issuance +1$)^{1}$ \\
\hline Log(Equity \& Debt Investment) & $\begin{array}{l}\text { Total value of } \log (\text { Equity Investment }) \text { and } \log (\text { Debt } \\
\text { Investment }) \text { as defined above }\end{array}$ \\
\hline Log(Audit Fees) & Natural $\log$ of (Total audit fees +1$)^{2}$ \\
\hline Specialist & $\begin{array}{l}\text { A dummy variable taking the value of } 1 \text { if the auditor } \\
\text { employed by an individual REIT performs more than } 30 \% \\
\text { of all REIT audits in the sample, and } 0 \text { otherwise }\end{array}$ \\
\hline Big 4 Auditor & $\begin{array}{l}\text { A dummy variable taking the value of } 1 \text { if the auditor ranks } \\
\text { as a Big } 4 \text { audit firm, and } 0 \text { otherwise }\end{array}$ \\
\hline Bid-Ask Spread & The standard deviation of the mean annual bid-ask spread \\
\hline Log(Intan. Assets) & Natural log of (Intangible assets +1$)$ \\
\hline Book-To-Market & Computed as book value divided by market value \\
\hline Return On Assets & Net annual income ${ }^{1}$ divided by total assets \\
\hline Leverage & Total assets divided by total liabilities \\
\hline Initial & $\begin{array}{l}\text { A dummy variable taking the value of } 1 \text { if an individual } \\
\text { REIT's audit firm is in either the first or second year of } \\
\text { engagement, and } 0 \text { otherwise }{ }^{3}\end{array}$ \\
\hline Log(Other Fees) & $\begin{array}{l}\text { Natural } \log \text { of }(\text { All non-audit fees }=\text { income tax preparation } \\
\text { services }+ \text { information systems consulting }+ \text { benefits } \\
\text { administration }+ \text { other non-audit fees }+1)^{2}\end{array}$ \\
\hline Log(Properties) & $\begin{array}{l}\text { The natural log of (Total number of properties owned or } \\
\text { controlled by the individual REITs or their respective } \\
\text { subsidiaries as reported in their annual } 10 \text {-k report }+1)^{5}\end{array}$ \\
\hline
\end{tabular}




\begin{tabular}{|c|c|}
\hline Log(Subsidiaries) & $\begin{array}{l}\text { The natural } \log \text { of (Total number of subsidiaries owned or } \\
\text { controlled by the individual REITs or their respective } \\
\text { subsidiaries as reported in their annual } 10-\mathrm{k} \text { report }+1)^{5}\end{array}$ \\
\hline Foreign & $\begin{array}{l}\text { A dummy variable taking the value of } 1 \text { if an individual } \\
\text { REIT has operations outside of the United States as } \\
\text { reported in CRSP/Compustat database, and } 0 \text { otherwise }\end{array}$ \\
\hline Extra/Disc Items & $\begin{array}{l}\text { A dummy variable taking the value of } 1 \text { if an individual } \\
\text { REIT has extraordinary items and/or discontinued } \\
\text { operations as reported in the CRSP/Compustat database, } \\
\text { and } 0 \text { otherwise }\end{array}$ \\
\hline REIT Type & $\begin{array}{l}\text { A dummy variable taking the value of } 1 \text { if an individual } \\
\text { REIT is } Y \text {-type, and } 0 \text { otherwise }\end{array}$ \\
\hline \multicolumn{2}{|c|}{$\begin{array}{l}\text { Notes: }{ }^{1} \text { Log values computed on values reported in the Compustat database. }{ }^{2} \text { Log values } \\
\text { computed on values reported in the Audit Analytics database. }{ }^{3} \text { Specific REIT audit and } \\
\text { auditor information reported in the Audit Analytics database. }{ }^{4} \text { The group of audit firms } \\
\text { currently known as the "Big 4" includes PriceWaterhouseCoopers, Deloitte \& Touche, Ernst } \\
\text { \& Young, and KPMG, ranked "1" through "4" based on annual revenues, respectively, as } \\
\text { reported at http://www.big4.com. "Specific, individual REIT 10-k annual reports accessed at } \\
\text { http://www.sec.gov. }{ }^{6} \text { REIT Type indicates type of REIT industry classification including } \\
\text { Multifamily, Manufacturing, Healthcare, Shopping Center, Freestanding, Regional Mall, } \\
\text { Lodging/Resort, Diversified, Office, Industrial, Office/Industrial Mixed, Self-Storage, } \\
\text { Commercial Mortgage, and Residential Mortgage. }\end{array}$} \\
\hline
\end{tabular}

As shown in Table 2 below, $17.35 \%$ of the REITs in the sample hold a diversified portfolio of properties. There are 11 multifamily and 11 residential REITs, accounting for $22.44 \%$ of the sample. Office, Healthcare, and Lodging and Resort REITs comprise $27.6 \%$ of the sample with nine properties each. 
Table 2. REIT-Type Distributions

\begin{tabular}{|c|c|c|c|}
\hline REIT Specialization & REIT Type & $\begin{array}{l}\text { \# of REITs } \\
\text { in Sample }\end{array}$ & $\begin{array}{l}\% \text { of REITs } \\
\text { in Sample }\end{array}$ \\
\hline Diversified Portfolio of Properties & Equity & 17 & $17.35 \%$ \\
\hline Multifamily Residential Properties & Equity & 11 & $11.22 \%$ \\
\hline Retail Shopping Center Properties & Equity & 11 & $11.22 \%$ \\
\hline Office Properties & Equity & 9 & $9.18 \%$ \\
\hline Healthcare Properties & Equity & 9 & $9.18 \%$ \\
\hline Lodging \& Resort Properties & Equity & 9 & $9.18 \%$ \\
\hline Retail Regional Mall Properties & Equity & 6 & $6.12 \%$ \\
\hline Residential Mortgage Investments & Mortgage & 6 & $6.12 \%$ \\
\hline Office \& Industrial Properties & Equity & 5 & $5.10 \%$ \\
\hline Freestanding Single-Tenant Properties & Equity & 4 & $4.08 \%$ \\
\hline Industrial Properties & Equity & 4 & $4.08 \%$ \\
\hline Residential Manufactured Home Properties & Equity & 3 & $3.06 \%$ \\
\hline Commercial Mortgage Investments & Mortgage & 3 & $3.06 \%$ \\
\hline Self-Storage \& Mini-Warehouse Properties & Equity & 1 & $1.02 \%$ \\
\hline TOTALS & & 98 & $100.00 \%$ \\
\hline \multicolumn{4}{|c|}{$\begin{array}{l}\text { Notes:98 REITs maintained REIT status during the entire sample period of 2002-2011 as } \\
\text { confirmed in specific, individual REIT 10-k annual reports. }\end{array}$} \\
\hline
\end{tabular}

Table 3 below presents selected financial data for the REITs in the sample. Total assets and liabilities average $\$ 4.19$ and $\$ 2.83$ billion, respectively, while average stockholder equity and long-term debt are $\$ 1.25$ and $\$ 1.85$ billion, respectively. On average, REITs have net income of $\$ 89.73$ million, on annual revenues of $\$ 581.79$ million. Mean equity investment in REITs is $\$ 133.28$ million, while debt investment averages $\$ 2.47$ billion. 
Table 3. Selected REIT Summary Statistics

\begin{tabular}{|c|c|c|c|c|c|c|}
\hline Variable & $\mathrm{N}$ & Mean & Std. Dev. & 25 th & Median & 75th \\
\hline Total Assets & 953 & 4191.31 & 6981.59 & 999.01 & 2252.66 & 4749.60 \\
\hline Intangible Assets & 953 & 51.73 & 245.25 & 0.00 & 0.00 & 11.90 \\
\hline Total Liabilities & 953 & 2829.91 & 5725.35 & 521.51 & 1408.01 & 2993.72 \\
\hline Long Term Debt & 953 & 1854.77 & 2572.82 & 327.08 & 1047.55 & 2206.24 \\
\hline Annual Revenues & 953 & 581.79 & 888.24 & 137.81 & 298.01 & 642.39 \\
\hline Earnings Before Interest \& Taxes & 953 & 190.09 & 315.80 & 45.44 & 103.90 & 226.28 \\
\hline Net Income & 953 & 89.73 & 219.60 & 12.09 & 45.56 & 128.61 \\
\hline Stockholder Equity & 953 & 1253.45 & 1615.30 & 302.20 & 774.85 & 1538.09 \\
\hline Equity Investment $^{1}$ & 953 & 133.28 & 314.73 & 1.16 & 32.63 & 158.19 \\
\hline Debt Investment ${ }^{1}$ & 953 & 2465.17 & 4998.52 & 453.69 & 1248.33 & 2557.69 \\
\hline Equity \& Debt Investment ${ }^{1}$ & 953 & 2598.26 & 5196.16 & 487.60 & 1354.85 & 2719.49 \\
\hline Audit Fees ${ }^{2}$ & 953 & 895.94 & 976.44 & 341.35 & 666.85 & 1060.50 \\
\hline Other Fees $^{2}$ & 953 & 420.02 & 885.92 & 47.00 & 159.55 & 378.76 \\
\hline Properties $^{3}$ & 953 & 245.79 & 369.18 & 32.00 & 111.00 & 273.00 \\
\hline Subsidiaries $^{3}$ & 953 & 137.12 & 284.99 & 14.00 & 45.00 & 147.00 \\
\hline \multicolumn{7}{|c|}{$\begin{array}{l}\text { Notes: All information is for the entire sample period of } 2002-2011 \text {. Audit Fees and Other } \\
\text { Fees expressed in } \$ 0,000 \text { 's; all other financial data presented in } \$ 0,000,000 \text { 's. }{ }^{1} \text { Financial data } \\
\text { are as reported in the CRSP/Compustat databases. }{ }^{2} \text { Audit and Other Fees are as reported in } \\
\text { the Audit Analytics database. }{ }^{3} \text { Properties and subsidiaries information are as reported in each } \\
\text { of the REITs' annual reports available at http://www.sec.gov. }\end{array}$} \\
\hline
\end{tabular}

\subsection{Research Design and Methodology}

In our examination of the relationship between REITs' use of the audit process to signal 


\section{Macrothink}

Asian Journal of Finance \& Accounting

ISSN 1946-052X 2018, Vol. 10, No. 1

financial transparency and their access to capital investment, the outcome of interest is Capital Investment, for which we proxy by using three investment measures: equity, debt, and combined equity and debt investment. We incorporate the audit-related attributes of auditor quality and auditor reputation (following Danielson et al., 2009), with auditor specialization to capture audit process transparency. In the first part of the analysis, the study period is much broader, covering the years of 2002-2011. In the second part of the analysis, we gauge the impact of the financial crisis.

\subsubsection{Empirical Model - Part 1}

In addition to the variables we use to capture the Transparency dimension as detailed below, we include three additional vectors of variables to capture the dimensions of Firm Characteristics, Auditor Relationship, and REIT Complexity. We also use a number of dummy variables to control for effects related to specific REIT-types and/or changes across time. The empirical model for the first part of the analysis takes the following form:

Capital Investment $=f\{$ Transparency, Firm Characteristics, Auditor Relationship, REIT

$$
\text { Complexity\}. }
$$

\subsubsection{Transparency Vector}

Earlier, we mention research findings that firms often pay higher audit fees to hire higher quality auditors to signal investors that their financial information is highly credible (Datar, Feltham, \& Hughes, 1991; Titman \& Trueman, 1986). Therefore, the central piece of the investigation centers on Transparency. To proxy for auditor quality, we use the variable Log(Audit Fees),(Note 6) which is the natural log of the sum of one and audit fees.(Note 7) To capture auditor specialization, we use the variable Specialist,(Note 8) a dummy variable that takes the value of one if the auditing firm has performed audits on more than $30 \%$ of the audits in the entire sample in each year, and zero otherwise. Finally, to proxy for auditor reputation, we use the variable Big 4 Auditor, (Note 9) a dummy variable that takes the value of one if the auditor ranks as one of the Big 4 audit firms, and zero otherwise. Table 4 below presents the REIT auditors contained in the sample, as well as number of audits performed, percentage of REIT audits performed, and fees paid to the auditors. 
Table 4. REIT Auditors.

\begin{tabular}{|c|c|c|c|c|c|}
\hline REIT Auditor Name & $\begin{array}{l}\text { REIT } \\
\text { Auditor } \\
\text { Rank }\end{array}$ & $\begin{array}{l}\text { \# REIT } \\
\text { Audits }\end{array}$ & $\begin{array}{l}\% \text { of } \\
\text { REIT } \\
\text { Audits }\end{array}$ & $\begin{array}{l}\text { Total } \\
\text { REIT } \\
\text { Audit } \\
\text { Fees } \\
(\$, 000 \mathrm{~s})\end{array}$ & $\begin{array}{l}\text { Average } \\
\text { Per-Audit } \\
\text { Fees } \\
(\$, 000 \mathrm{~s})\end{array}$ \\
\hline Ernst \& Young & 1 & 317 & $33.37 \%$ & 361,702 & 1,141 \\
\hline KPMG & 2 & 168 & $17.86 \%$ & 133,336 & 794 \\
\hline PricewaterhouseCoopers & 3 & 163 & $17.04 \%$ & 139,498 & 856 \\
\hline Deloitte \& Touche & 4 & 118 & $12.04 \%$ & 128,541 & 1,089 \\
\hline BDO USA & 5 & 69 & $7.04 \%$ & 42,508 & 616 \\
\hline Grant Thornton & 6 & 43 & $5.00 \%$ & 29,249 & 680 \\
\hline PKF O’Connor Davies & 7 & 14 & $1.43 \%$ & 3,077 & 220 \\
\hline Reznick Group & 8 & 14 & $1.43 \%$ & 1,736 & 124 \\
\hline Berenfeld Spritzer Shechter \& Sheer & 9 & 8 & $0.82 \%$ & 667 & 83 \\
\hline Swalm \& Associates & 10 & 8 & $0.82 \%$ & 451 & 56 \\
\hline McGladrey \& Pullen & 11 & 7 & $0.71 \%$ & 1,662 & 237 \\
\hline Burr Pilger Mayer & 12 & 6 & $0.61 \%$ & 1,690 & 282 \\
\hline Calvetti Ferguson \& Wagner & 13 & 5 & $0.51 \%$ & 7,286 & 1,457 \\
\hline Moss Adams & 14 & 5 & $0.51 \%$ & 653 & 131 \\
\hline Donaldson Holman \& West & 15 & 2 & $0.20 \%$ & 1,402 & 701 \\
\hline Epstein Weber \& Conover & 16 & 2 & $0.20 \%$ & 154 & 77 \\
\hline Moore Stephens & 17 & 1 & $0.10 \%$ & 79 & 79 \\
\hline Cherry Bekaert \& Holland & 18 & 1 & $0.10 \%$ & 77 & 77 \\
\hline Brady Martz \& Associates & 19 & 1 & $0.10 \%$ & 51 & 51 \\
\hline Farmer Fuqua \& Huff & 20 & 1 & $0.10 \%$ & 10 & 10 \\
\hline Totals & & 953 & $100.00 \%$ & 853,829 & 896 \\
\hline \multicolumn{6}{|c|}{$\begin{array}{l}\text { Notes:REIT Auditor Rank ranked first by the number of REIT audits performed and then by } \\
\text { the total audit fees for REIT auditsas reported in Audit Analytics database. }\end{array}$} \\
\hline
\end{tabular}

Previously, we discuss the association between information asymmetry, financial transparency, and the bid-ask spread. Researchers frequently use bid-ask spread as an indicator of transparency (Bagehot, 1971; Demsetz, 1968). Intangible assets are difficult to 
define or value, aggravated by the fact that firms often choose not to reveal certain information that they view as proprietary. Researchers commonly use intangible assets to proxy for information asymmetry or opacity. Therefore, we include two additional variables within the Transparency Vector: Bid-Ask Spread, which we construct using the standard deviation of the mean annual bid-ask spread of each REIT's stock price; and Log(Intang Assets), which is the natural log of the sum of one and the total value of each REIT's intangible assets.(Note 10)

\subsubsection{Firm Characteristics Vector}

Within the sample, REITs vary by type, size, and industry focus. To capture and control for the differences between them, we use variables within the Firm Characteristics Vector. First in the group is Book-To-Market, which we calculate by dividing book value (total assets minus total liabilities and total intangible assets) by market value (common shares outstanding at year's end multiplied by share price at year's end). The second variable is Return-On-Assets, the result of dividing net income by total assets. Rounding out the Firm Characteristics Vector is Leverage, which we compute by dividing total liabilities by total assets.

\subsubsection{Auditor Relationship Vector}

In addition to the three audit-related attributes of auditor quality, specialization, and reputation, we also use a vector of two additional observable variables to control for other aspects of the relationship between the audit firm and its client. Investors understand that over time auditors gain significant understanding about the nature of their clients' business operations (AICPA, 1978; Bells, Marrs, Solomon, \& Thomas, 1997), and numerous researchers find a positive association between auditor tenure and audit quality (Geiger \& Raghunanandan, 2002; Johnson, Khurana \& Reynolds, 2002; Myers, Myers, \& Omer, 2003; Mansi, Maxwell, \& Miller, 2004). To control for the possible learning curve facing a new auditor, in the Auditor Relationship Vector we include Initial, a dummy variable taking the value of one if the current auditor is in either the first or second year of engagement, and zero otherwise. Audit firms commonly provide clients with non-audit services such as tax preparation, risk management, and pension plan administration consulting services. Fees for these types of services can often exceed those paid for audits. Some researchers theorize that audit firms price audit services somewhat as a 'loss-leader' in order to gain a foothold in to a firm, thus paving the way for the provision of more profitable 'non-audit' services (Antle, Gordon, Narayanamoorthy, \& Zhou, 2006; Knechel \& Sharma 2012). Even so, regulators have long had concerns about the relationship between an auditor and its client, and the relationship's impact on firm transparency. In 2001, the U.S. Securities and Exchange Commission began requiring full disclosure of audit and non-audit fees amidst concerns over firm transparency, audit and non-audit fees, and auditor independence (Danielson et al., 2009). Less than two years later, the U.S. Congress went even further when they passed the Sarbanes-Oxley Act of 2002, which established stringent new standards designed to enhance auditor independence and limit conflicts of interest (Naiker, Sharma, \& Sharma, 2013). Because the rationale is that high non-audit fees weaken auditor independence, and hence, by 
extension, reduce audit quality, non-audit fees can influence investors' perceptions of firm transparency. Although the research in this paper does not specifically explore the impact of non-audit fees, we include the variable $\log$ (Other Fees), the natural log of the sum of non-audit fees and one, (Note 11) to control for the impact of non-audit fees.

\subsubsection{REIT Complexity Vector}

As we discuss earlier, auditing REITs is often a complex process, partly because REITs operate in a highly regulated environment, and partly because of the means used to value investments within their portfolios. We include a number of observable variables within the REIT Complexity Vector to capture the complex asset types and/or corporate structures associated with the REITs within the sample. The variables we use include $\log$ (Subsidiaries), the natural $\log$ of the sum of one and the total number of subsidiaries owned or controlled by the REIT; (Note 12) Log(Properties), the natural log of the sum of one and the total number of properties owned or controlled by the REIT or one of its subsidiaries;(Note 13) Foreign, a dummy variable taking the value of one if the REIT conducts business outside of the United States, and zero otherwise; and Extra/Disc Items, a dummy variable taking the value of one if the REIT has extraordinary items or discontinued operations, and zero otherwise. Within the sample, there are 12 different equity REITs and 2 different mortgage REITs, so for robustness, we also use dummy variables to control for each of the different REIT-types.

\subsubsection{Testable Equation for Hypotheses 1-3}

To test each of Hypotheses 1-3, we conduct four separate estimations. In the first three estimations, we individually test each of the audit-related attributes. In the fourth estimation, we combine all attributes together. We do this to account for any potential collinearity problems that may occur from grouping all variables within the same model. Again, using data from all REITs during the entire sample period, the outcome of interest is Capital Investment, which we capture using equity, debt, and combined equity and debt investment, using the testable form of Equation (1) as follows:

Capital Investment $=\beta 0+\beta 1 \cdot \log ($ Audit Fees $)+\beta 2 \cdot$ Specialist $+\beta 3 \cdot$ Big 4 Auditor $+\beta 4 \cdot$ Bid-Ask Spread $+\beta 5 \cdot \log ($ Intan Assets $)+\beta 6 \cdot$ Book-To-Market $+\beta 7 \cdot$ Return-On-Assets + $\beta 8 \cdot$ Leverage $+\beta 9 \cdot$ Initial $+\beta 10 \cdot \log ($ OtherFees $)+\beta 11 \cdot \log ($ Properties $)+\beta 12 \cdot \log ($ Subsidiaries $)$

$$
+\beta 13 \cdot \text { Foreign }+\beta 14 \cdot \text { Extra } / \text { Disc Items }+\beta 15-26 \cdot \text { REIT Type }+\varepsilon \text {. }
$$

\subsubsection{Empirical Model - Part 2}

Thus far, the research question examines the relationship between REITs' use of the audit process as a means to convey increased financial transparency and access to capital investment. In the second part of the analysis, we consider the impact of the financial crisis. After adding a fifth vector, Financial Crisis, the extended empirical model takes the following form:

\section{Capital Investment $=f_{0}\{$ Transparency, Firm Characteristics, Auditor Relationship, REIT}

$$
\text { Complexity, Financial Crisis\}. }
$$




\subsubsection{Financial Crisis Vector}

Using the model shown in the form of Equation (2), we add additional variables within the Financial Crisis Vector to investigate the interactive effects between the crisis and each of the audit-related attributes. The first variable added is Crisis, a dummy variable that takes the value of one for the period 2008-2011, and zero for the period 2002-2007. We also add three interaction terms. First, we use Crisis ${ }^{*} \log ($ Audit Fees), which captures the interaction between Crisis and Log(Audit Fees), to measure whether or not the relationship between audit fees and capital investment is affected by the financial crisis. Second, we use Crisis*Specialist, which captures the interaction between Crisis and Specialist, to measure whether or not the relationship between industry-audit specialist and capital investment is affected by the financial crisis. Third, we use Crisis*Big 4 Auditor, which captures the interaction between Crisis and Big 4 Auditor, to measure whether or not the relationship between Big 4 auditor and capital investment is affected by the financial crisis. The testable form of Equation (3) is as follows:

Capital Investment $=\beta 0+\beta 1 \cdot$ Crisis $+\beta 2 \cdot \log$ (Audit Fees) $+\beta 3 \cdot$ Crisis ${ }^{*} \log$ (Audit Fees $)+$ $\beta 4 \cdot$ Specialist $+\beta 5 \cdot$ Crisis $*$ Specialist $+\beta 6 \cdot$ Big 4 Auditor $+\beta 7 \cdot$ Crisis $*$ Big 4 Auditor + $\beta 8 \cdot$ Bid-Ask Spread $+\beta 9 \cdot \log ($ Intan Assets $)+\beta 10 \cdot$ Book-To-Market $+\beta 11 \cdot$ Return-On-Assets + $\beta 12 \cdot$ Leverage $+\beta 13 \cdot$ Initial $+\beta 14 \cdot \log ($ Other Fees $)+\beta 15 \cdot \log$ (Properties) + $\beta 16 \cdot \log ($ Subsidiaries $)+\beta 17 \cdot$ Foreign $+\beta 18 \cdot$ Extra $/$ Disc Items $+\beta 19-30 \cdot$ REIT Type $+\varepsilon$.

We test each hypothesis using robust regression estimations. We also account for the possibility of any firm- or time-related invariant characteristics affecting the REITs within the sample. For example, a diversified REIT that invests in different types of properties, such as regional shopping malls, office properties, or timberland, may have entirely different factors affecting their abilities to raise capital, than for example, a REIT that only invests in one type of property. Likewise, as business cycles change over time, it is possible that a REIT that invests strictly in one property type, for example retail properties, may experience different investor responses when seeking equity as opposed to another type of REIT. This may be due to one particular property sector falling out of favor as an investment, or having trouble at one point in time versus other types of REITs in the same period. Therefore, in addition to using dummy variables for each firm year to account for changes over time, we also use dummies to control for the different types of REITs within the sample.

\section{Results and Discussion}

\subsection{Descriptive Statistics}

Table 3 referenced above shows that on average, REITs issue $\$ 133$ million in equity and $\$ 2,465$ million in debt annually, for a combined annual total of $\$ 2,598$ million. Audit fees and non-audit fees average $\$ 895,938$ thousand and $\$ 420,018$ thousand, respectively. REITs in the sample own an average of 246 properties, and have 137 subsidiaries. Table 5 below presents descriptive statistics for all variables that we use in the regression analyses. More than a third of the firms in the sample use a REIT industry-audit specialist, nearly all use a Big 4 auditor, and close to $20 \%$ of auditors are in their first or second year of engagement. Only a fraction 


\section{Macrothink}

Asian Journal of Finance \& Accounting ISSN 1946-052X 2018, Vol. 10, No. 1

of REITs conducts foreign operations. Slightly more than half of the audits report either an extraordinary item (a net income adjustment made due to an unusual or infrequent occurrence, such as a loss due to a hurricane), or a discontinued operation (a net income adjustment made because a portion of a company's operation is discontinued, such as due to the sale of an asset).

Table 5. Descriptive Statistics: Dependent \& Independent Variables

\begin{tabular}{|c|c|c|c|c|c|c|}
\hline Variable & $\mathrm{N}$ & Mean & Std. Dev. & 25 th & Median & 75th \\
\hline Log(Equity Investment) & 953 & 3.132471 & 2.217645 & 0.77 & 3.52 & 5.07 \\
\hline Log(Debt Investment) & 953 & 6.792827 & 1.707107 & 6.12 & 7.13 & 7.85 \\
\hline Log(Equity \& Debt Investment) & 953 & 6.880828 & 1.680798 & 6.19 & 7.21 & 7.91 \\
\hline Log(Audit Fees) & 953 & 13.28539 & 0.9523914 & 12.74 & 13.41 & 13.87 \\
\hline Specialist & 953 & 0.3326338 & 0.471404 & 0.00 & 0.00 & 1.00 \\
\hline Big 4 Auditor & 953 & 0.9223505 & 0.2677598 & 1.00 & 1.00 & 1.00 \\
\hline Bid-Ask Spread & 953 & 0.0043952 & 0.00625 & 0.00 & 0.00 & 0.00 \\
\hline Log(Intangible Assets) & 953 & 1.351846 & 1.936908 & 0.00 & 0.00 & 2.56 \\
\hline Book-To-Market Ratio & 953 & 0.5723122 & 2.181254 & 0.35 & 0.52 & 0.72 \\
\hline Return On Assets & 953 & 0.0263103 & 0.0562677 & 0.01 & 0.03 & 0.05 \\
\hline Leverage & 953 & 0.6018785 & 0.1928988 & 0.50 & 0.59 & 0.70 \\
\hline Initial & 953 & 0.1867786 & 0.3899383 & 0.00 & 0.00 & 0.00 \\
\hline Log(Other Fees) & 953 & 11.27902 & 3.13359 & 10.76 & 11.98 & 12.84 \\
\hline Log(Properties) & 953 & 4.258593 & 2.04574 & 3.50 & 4.72 & 5.61 \\
\hline Log(Subsidiaries) & 953 & 3.805615 & 1.611061 & 2.71 & 3.83 & 5.00 \\
\hline Foreign & 953 & 0.0209864 & 0.1434138 & 0.00 & 0.00 & 0.00 \\
\hline Extra.\& Disc. Items & 953 & 0.5299056 & 0.4993669 & 0.00 & 1.00 & 1.00 \\
\hline \multicolumn{7}{|c|}{$\begin{array}{l}\text { Notes: The table above presents descriptive statistics for the variables used in the regressions } \\
\text { (except for REIT-type and Year Dummies). }\end{array}$} \\
\hline
\end{tabular}

\subsection{Results of Hypothesis Testing}

In the initial empirical analysis, we test Hypotheses 1. We expect to find a positive relationship between the audit process and equity, debt, and combined equity and debt capital investment in REITs, respectively. Positive and significant coefficients for individual audit-related attributes would indicate support for the hypotheses with respect to each attribute. In the extended empirical analysis, we test Hypotheses 2. We expect to find that capital investment is lower for all REITs after the financial crisis because of the significant 
drop in financial markets activity after the crisis. Negative and significant coefficients for the financial crisis dummy would confirm this expectation. We also expect to find that after the crisis, REITs that utilize the audit process to increase financial transparency would experience greater equity, debt, and combined equity and debt capital investment than REITs that did not do so. Positive and significant coefficients for the interaction terms will confirm these expectations, and allow interpretation of the main effects of the individual audit-related attributes.

\subsubsection{Hypothesis 1 Results}

Table 6 below shows the results for testing Hypothesis 1(a) that there is a positive association between the audit process and equity investment in REITs. In Models 1a and 1b, the coefficients for Log(Audit Fees) and Specialist are positive and significant (Log(Audit Fees), $\beta=0.421$ and Specialist, $\beta=0.358$, respectively). Model 1d yields similar results (Log(Audit Fees), $\beta=0.409$ and Specialist, $\beta=0.278$, respectively). These results provide partial support for the hypothesis, suggesting that investors view REITs that either pay higher audit fees or engage industry-audit specialists as more transparent, and are willing to provide equity investment.

Table 6. Results of OLS Regression testing the expectation of a positive association between audit-related attributes and equity investment in REITs

\begin{tabular}{|l|c|c|c|c|}
\hline \multirow{2}{*}{ Variable } & Model 1a & Model 1b & Model 1c & Model 1d \\
\cline { 2 - 5 } & Coefficient & Coefficient & Coefficient & Coefficient \\
\cline { 2 - 5 } & {$[\mathrm{t}-$ Statistic] } & {$[$ t-Statistic] } & {$[$ t-Statistic] } & [t-Statistic] \\
\hline Log(Audit Fees) & $0.421^{* * *}$ & & & $0.409 * * *$ \\
\hline & {$[3.701]$} & & & {$[3.341]$} \\
\hline Specialist & & $0.358^{* *}$ & & $0.278^{*}$ \\
\hline & & {$[2.383]$} & & {$[1.841]$} \\
\hline Big 4 Auditor & & & 0.155 & -0.218 \\
\hline & & & {$[0.620]$} & {$[-0.794]$} \\
\hline Bid-Ask Spread & $-71.044 * * *$ & $-84.971^{* * *}$ & $-83.848 * * *$ & $-74.153 * * *$ \\
\hline & {$[-6.059]$} & {$[-7.530]$} & {$[-6.619]$} & {$[-5.950]$} \\
\hline Log(Intan. Assets) & $0.082^{*}$ & $0.111^{* *}$ & $0.110 * *$ & $0.084 *$ \\
\hline & {$[1.896]$} & {$[2.526]$} & {$[2.515]$} & {$[1.916]$} \\
\hline Book-To-Market & $0.064 * * *$ & $0.062 * * *$ & $0.058^{* * *}$ & $0.067 * * *$ \\
\hline & {$[3.353]$} & {$[3.301]$} & {$[3.185]$} & {$[3.434]$} \\
\hline Return On Assets & -0.496 & -0.762 & -0.696 & -0.576 \\
\hline
\end{tabular}




\begin{tabular}{|c|c|c|c|c|}
\hline & {$[-0.472]$} & {$[-0.716]$} & {$[-0.668]$} & {$[-0.535]$} \\
\hline \multirow[t]{2}{*}{ Leverage } & -0.331 & -0.096 & -0.084 & -0.313 \\
\hline & {$[-0.753]$} & {$[-0.222]$} & {$[-0.191]$} & {$[-0.713]$} \\
\hline \multirow[t]{2}{*}{ Initial Auditor Year } & 0.058 & 0.036 & 0.038 & 0.044 \\
\hline & {$[0.331]$} & {$[0.206]$} & {$[0.215]$} & {$[0.247]$} \\
\hline \multirow[t]{2}{*}{ Log(Other Fees) } & $0.050 * *$ & $0.066^{* * *}$ & $0.071 * * *$ & $0.048 *$ \\
\hline & [2.002] & [2.789] & [2.938] & [1.920] \\
\hline \multirow[t]{2}{*}{ Log(Properties) } & $0.208 * * *$ & $0.208 * * *$ & $0.233 * * *$ & $0.191 * * *$ \\
\hline & [4.029] & {$[3.901]$} & [4.419] & {$[3.651]$} \\
\hline \multirow[t]{2}{*}{ Log(Subsidiaries) } & $0.106^{*}$ & $0.192 * * *$ & $0.171 * * *$ & $0.126^{* *}$ \\
\hline & {$[1.774]$} & {$[3.444]$} & {$[3.027]$} & [2.114] \\
\hline \multirow[t]{2}{*}{ Foreign Operations } & -0.704 & -0.436 & -0.355 & -0.759 \\
\hline & {$[-1.321]$} & {$[-0.797]$} & {$[-0.667]$} & {$[-1.391]$} \\
\hline \multirow[t]{2}{*}{ Extra/Disc Items } & -0.011 & 0.064 & 0.043 & 0.010 \\
\hline & {$[-0.082]$} & {$[0.456]$} & {$[0.301]$} & {$[0.071]$} \\
\hline \multirow[t]{2}{*}{ Constant } & -2.029 & $2.474 * * *$ & $2.484 * * *$ & -1.811 \\
\hline & {$[-1.517]$} & {$[4.789]$} & [4.441] & {$[-1.331]$} \\
\hline \# Observations & 953 & 953 & 953 & 953 \\
\hline $\mathrm{F}$ & 17.759 & 16.396 & 16.651 & 17.103 \\
\hline Adjusted R2 & 0.261 & 0.255 & 0.250 & 0.263 \\
\hline \multicolumn{5}{|c|}{$\begin{array}{l}\text { Notes: In all models, the dependent variable is } \log (\text { Equity Investment), with the model } \\
\text { variation being the respective inclusion or exclusion of } \log \text { (Audit Fees), Specialist, and Big } 4 \\
\text { Auditor. Bid-Ask Spread is an often-used measure to capture transparency. Log(Intan. Assets) } \\
\text { captures firm's level of information asymmetry or opacity.Book-To-Market, Return On Assets, } \\
\text { and Leverage capture individual REIT firm characteristics. Initial and Log(Other Fees) } \\
\text { capture individual REIT-auditor relationships. Log(Properties), Log(Subsidiaries), Foreign, } \\
\text { and Extra/Disc Items capture firm complexity. REIT Type and Year Dummies not reported. } \\
\text { Regression estimations are robust and statistical significance shown as: }{ }^{*} \mathrm{p}<0.05,{ }^{* *} \mathrm{p}< \\
0.01,{ }^{* *} \mathrm{p}<0.001 \text {, respectively. }\end{array}$} \\
\hline
\end{tabular}

Table 7 below shows the results for testing Hypothesis 1(b) that there is a positive association between the audit process and debt investment in REITs. Results show stronger, albeit still partial support for the hypothesis. In Models 2a, 2b, and 2c, the coefficients for each of the audit-related attributes are positive and significant (Log(Audit Fees), $\beta=0.697$; Specialist, $\beta$ $=0.368$; and, Big 4 Auditor, $\beta=0.454$, respectively), while in Model 2d, only the coefficients 


\section{Macrothink Institute ${ }^{\mathrm{TM}}$}

for $\log$ (Audit Fees) and Specialist are positive and significant $(\beta=0.679$ and $\beta=0.218$, respectively). When viewed independently of each other, these results suggest that investors are willing to invest in REIT debt when REITs increase their financial transparency (as captured by higher audit fees or hiring industry-audit specialists or hiring auditors with higher reputations).

Table 7. Results of OLS Regression testing the expectation of a positive association between audit-related attributes and debt investment in REITs

\begin{tabular}{|c|c|c|c|c|}
\hline \multirow{3}{*}{ Variable } & Model 2a & Model 2b & Model 2c & Model 2d \\
\hline & Coefficient & Coefficient & Coefficient & Coefficient \\
\hline & [t-Statistic] & [t-Statistic] & [t-Statistic] & [t-Statistic] \\
\hline \multirow[t]{2}{*}{ Log(Audit Fees) } & $0.697 * * *$ & & & $0.679 * * *$ \\
\hline & {$[10.701]$} & & & [9.740] \\
\hline \multirow[t]{2}{*}{ Specialist } & & $0.368 * * *$ & & $0.218 * * *$ \\
\hline & & [5.412] & & [3.344] \\
\hline \multirow[t]{2}{*}{ Big 4 Auditor } & & & $0.454 * * *$ & -0.104 \\
\hline & & & [3.860] & {$[-0.929]$} \\
\hline \multirow[t]{2}{*}{ Bid-Ask Spread } & $-45.816^{* * *}$ & $-69.949 * * *$ & $-63.406 * * *$ & $-47.313 * * *$ \\
\hline & {$[-6.644]$} & {$[-9.230]$} & {$[-8.171]$} & {$[-6.795]$} \\
\hline \multirow[t]{2}{*}{ Log(Intan. Assets) } & 0.028 & $0.074 * * *$ & $0.072 * * *$ & 0.029 \\
\hline & {$[1.263]$} & {$[3.253]$} & [3.186] & {$[1.327]$} \\
\hline \multirow[t]{2}{*}{ Book-To-Market } & $0.071 * * *$ & $0.064 * * *$ & $0.061 * * *$ & $0.073 * * *$ \\
\hline & [4.487] & [4.513] & [4.294] & {$[4.550]$} \\
\hline \multirow[t]{2}{*}{ Return On Assets } & 0.741 & 0.321 & 0.454 & 0.690 \\
\hline & [1.529] & [0.629] & {$[0.900]$} & {$[1.405]$} \\
\hline \multirow[t]{2}{*}{ Leverage } & $3.946 * * *$ & $4.362 * * *$ & $4.317 * * *$ & $3.952 * * *$ \\
\hline & [13.367] & [13.911] & {$[13.628]$} & {$[13.382]$} \\
\hline \multirow[t]{2}{*}{ Initial Auditor Year } & 0.080 & 0.035 & 0.070 & 0.076 \\
\hline & {$[1.077]$} & {$[0.433]$} & {$[0.845]$} & {$[1.000]$} \\
\hline \multirow[t]{2}{*}{$\log ($ Other Fees $)$} & 0.002 & $0.032 * * *$ & $0.035 * * *$ & 0.000 \\
\hline & {$[0.246]$} & {$[3.547]$} & {$[3.765]$} & {$[0.037]$} \\
\hline \multirow[t]{2}{*}{ Log(Properties) } & $0.251 * * *$ & $0.267 * * *$ & $0.290 * * *$ & $0.237 * * *$ \\
\hline & [5.611] & {$[5.677]$} & [6.193] & [5.278] \\
\hline
\end{tabular}




\begin{tabular}{|c|c|c|c|c|}
\hline \multirow[t]{2}{*}{ Log(Subsidiaries) } & $0.064 * *$ & $0.195 * * *$ & $0.168 * * *$ & $0.080 * *$ \\
\hline & [2.011] & {$[5.677]$} & [4.866] & [2.464] \\
\hline \multirow[t]{2}{*}{ Foreign Operations } & -0.310 & 0.183 & 0.271 & -0.345 \\
\hline & {$[-1.219]$} & {$[0.608]$} & [1.018] & {$[-1.263]$} \\
\hline \multirow[t]{2}{*}{ Extra/Disc Items } & $0.178 * *$ & $0.293 * * *$ & $0.261 * * *$ & $0.194 * * *$ \\
\hline & {$[2.457]$} & {$[3.835]$} & {$[3.370]$} & [2.692] \\
\hline \multirow[t]{2}{*}{ Constant } & $-4.079 * * *$ & $3.477 * * *$ & $3.209 * * *$ & $-3.884 * * *$ \\
\hline & {$[-4.728]$} & {$[9.261]$} & [8.132] & {$[-4.427]$} \\
\hline \# Observations & 953 & 953 & 953 & 953 \\
\hline $\mathrm{F}$ & 79.981 & 60.441 & 61.604 & 79.313 \\
\hline Adjusted R2 & 0.713 & 0.670 & 0.665 & 0.715 \\
\hline \multicolumn{5}{|c|}{$\begin{array}{l}\text { Notes: In all models, the dependent variable is } \log (\text { Debt Investment), with the model } \\
\text { variation being the respective inclusion or exclusion of } \log (\text { Audit Fees), Specialist, and Big } 4 \\
\text { Auditor. Bid-Ask Spread is an often-used measure to capture transparency. Log(Intan. Assets) } \\
\text { captures firm's level of information asymmetry or opacity.Book-To-Market, Return On Assets, } \\
\text { and Leverage capture individual REIT firm characteristics. Initial and Log(Other Fees) } \\
\text { capture individual REIT-auditor relationships. Log(Properties), Log(Subsidiaries), Foreign, } \\
\text { and Extra/Disc Items capture firm complexity. REIT Type and Year Dummies not reported. } \\
\text { Regression estimations are robust and statistical significance shown as: }{ }^{*} \mathrm{p}<0.05, * * \mathrm{p}< \\
0.01, * * * \mathrm{p}<0.001 \text {, respectively. }\end{array}$} \\
\hline
\end{tabular}

Table 8 below shows the results of testing Hypothesis 1(c) that there is a positive association between the audit process and combined equity and debt investment in REITs. In Models 3a, $3 \mathrm{~b}$, and 3c, the coefficients for $\log$ (Audit Fees), Specialist, and Big 4 Auditor are all positive and significant $(\beta=0.693, \beta=0.384$, and $\beta=0.497$, respectively). However, in Model $3 \mathrm{~d}$, only the coefficients for $\log$ (Audit Fees) and Specialist are positive and significant ( $\beta=$ 0.668 and $\beta=0.234$, respectively). These results suggest that investors are willing to invest in REIT equity and debt when REITs increase their financial transparency (either as captured by higher audit fees, hiring industry-audit specialists, or hiring auditors with higher reputations). 
Table 8. Results of OLS Regression testing the expectation of a positive association between audit-related attributes and combined equity and debt investment in REITs

\begin{tabular}{|c|c|c|c|c|}
\hline \multirow{3}{*}{ Variable } & Model 3a & Model 3b & Model 3c & Model 3d \\
\hline & Coefficient & Coefficient & Coefficient & Coefficient \\
\hline & [t-Statistic] & [t-Statistic] & [t-Statistic] & [t-Statistic] \\
\hline \multirow[t]{2}{*}{ Log(Audit Fees) } & $0.693 * * *$ & & & $0.668 * * *$ \\
\hline & [10.499] & & & [9.447] \\
\hline \multirow[t]{2}{*}{ Specialist } & & $0.384 * * *$ & & $0.234 * * *$ \\
\hline & & [5.613] & & {$[3.541]$} \\
\hline \multirow[t]{2}{*}{ Big 4 Auditor } & & & $0.497 * * *$ & -0.057 \\
\hline & & & {$[4.228]$} & {$[-0.501]$} \\
\hline \multirow[t]{2}{*}{ Bid-Ask Spread } & $-48.196 * * *$ & $-72.102 * * *$ & $-64.863 * * *$ & $-49.043 * * *$ \\
\hline & {$[-6.971]$} & {$[-9.466]$} & {$[-8.317]$} & {$[-7.003]$} \\
\hline \multirow[t]{2}{*}{ Log(Intan. Assets) } & 0.032 & $0.078 * * *$ & $0.076^{* * *}$ & 0.034 \\
\hline & {$[1.457]$} & {$[3.430]$} & {$[3.361]$} & {$[1.540]$} \\
\hline \multirow[t]{2}{*}{ Book-To-Market } & $0.062 * * *$ & $0.056^{* * *}$ & $0.053 * * *$ & $0.064 * * *$ \\
\hline & [4.249] & {$[4.175]$} & [3.935] & [4.322] \\
\hline \multirow[t]{2}{*}{ Return On Assets } & 0.484 & 0.065 & 0.209 & 0.438 \\
\hline & [0.959] & {$[0.121]$} & {$[0.404]$} & {$[0.846]$} \\
\hline \multirow[t]{2}{*}{ Leverage } & $3.468 * * *$ & $3.879 * * *$ & $3.828 * * *$ & $3.468 * * *$ \\
\hline & {$[11.731]$} & [12.393] & {$[12.124]$} & {$[11.722]$} \\
\hline \multirow[t]{2}{*}{ Initial Auditor Year } & 0.079 & 0.035 & 0.075 & 0.081 \\
\hline & {$[1.057]$} & {$[0.436]$} & {$[0.893]$} & {$[1.051]$} \\
\hline \multirow[t]{2}{*}{ Log(Other Fees) } & 0.008 & $0.038^{* * *}$ & $0.041 * * *$ & 0.006 \\
\hline & {$[0.883]$} & {$[4.091]$} & {$[4.268]$} & [0.699] \\
\hline \multirow[t]{2}{*}{ Log(Properties) } & $0.244 * * *$ & $0.258 * * *$ & $0.282^{* * *}$ & $0.228 * * *$ \\
\hline & {$[5.404]$} & {$[5.449]$} & {$[5.986]$} & {$[5.0370]$} \\
\hline \multirow[t]{2}{*}{ Log(Subsidiaries) } & $0.074 * *$ & $0.205^{* * *}$ & $0.177 * * *$ & $0.091 * * *$ \\
\hline & {$[2.305]$} & [5.954] & [5.099] & {$[2.781]$} \\
\hline Foreign Operations & -0.388 & 0.098 & 0.191 & -0.420 \\
\hline
\end{tabular}




\begin{tabular}{|c|c|c|c|c|}
\hline & {$[-1.561]$} & {$[0.331]$} & [0.734] & {$[-1.565]$} \\
\hline \multirow[t]{2}{*}{ Extra/Disc Items } & $0.138^{*}$ & $0.253 * * *$ & $0.218 * * *$ & $0.154 * *$ \\
\hline & {$[1.885]$} & {$[3.291]$} & [2.812] & [2.117] \\
\hline \multirow[t]{2}{*}{ Constant } & $-3.670 * * *$ & $3.834 * * *$ & $3.533 * * *$ & $-3.443 * * *$ \\
\hline & {$[-4.203]$} & {$[10.082]$} & [8.875] & {$[-3.876]$} \\
\hline \# Observations & 953 & 953 & 953 & 953 \\
\hline $\mathrm{F}$ & 75.038 & 57.086 & 58.786 & 74.847 \\
\hline Adjusted R2 & 0.700 & 0.657 & 0.652 & 0.702 \\
\hline \multicolumn{5}{|c|}{$\begin{array}{l}\text { Notes: In all models, the dependent variable is } \log (\text { Equity \& Debt Investment), with the } \\
\text { model variation being the respective inclusion or exclusion of } \log \text { (Audit Fees), Specialist, } \\
\text { and Big } 4 \text { Auditor. Bid-Ask Spread is an often-used measure to capture transparency. } \\
\text { Log(Intan.Assets) captures firm's level of information asymmetry or opacity.Book-To-Market, } \\
\text { Return On Assets, and Leverage capture individual REIT firm characteristics. Initial and } \\
\log (\text { Other Fees) capture individual REIT-auditor relationships. Log(Properties), } \\
\log (\text { Subsidiaries }), \text { Foreign, and Extra/Disc Items capture firm complexity. REIT Type and } \\
\text { Year Dummies not reported. Regression estimations are robust and statistical significance } \\
\text { shown as: } * \mathrm{p}<0.05, * * \mathrm{p}<0.01, * * * \mathrm{p}<0.001 \text {, respectively. }\end{array}$} \\
\hline
\end{tabular}

\subsubsection{Hypothesis 2 Results}

Table 9 below shows the results for testing Hypothesis 2(a) that the financial crisis positively influenced the relationship between the audit process and equity investment in REITs. As stated earlier, the financial crisis caused major disruptions in the capital markets, resulting in capital flight, and conditions of severe illiquidity. Therefore, we expect to find that there was less equity investment for all REITs post crisis. Thus, an important question is how REITs differentiate themselves from others seeking capital under such restricted market conditions. Across all models, there is no statistical significance for Crisis. This result provides no support for our expectation that equity capital investment is lower for all REITs after the financial crisis due to financial market decline. Additionally, there is no statistical significance for the interaction terms Crisis*Audit Fees, Crisis*Specialist, and Crisis*Big 4 Auditor. Accordingly, we are unable to interpret the main effects of the individual audit-related attributes. A reasonable inference from these results is that when seeking equity investment, using the audit process as a means of increasing financial transparency is important irrespective of the state of the economy. 
Table 9. Results of OLS Regression testing the expectation that the financial crisis of 2007-2008 positively influenced the relationship between audit-related attributes and equity investment in REITs

\begin{tabular}{|c|c|c|c|c|}
\hline \multirow{3}{*}{ Variable } & Model 4a & Model 4b & Model 4c & Model 4d \\
\hline & Coefficient & Coefficient & Coefficient & Coefficient \\
\hline & [t-Statistic] & [t-Statistic] & [t-Statistic] & [t-Statistic] \\
\hline \multirow[t]{2}{*}{ Crisis } & -1.045 & 0.172 & 0.198 & -1.153 \\
\hline & {$[-0.502]$} & {$[0.559]$} & [0.451] & {$[-0.471]$} \\
\hline \multirow[t]{2}{*}{ Crisis*Log(Audit Fees) } & 0.067 & & & 0.069 \\
\hline & {$[0.424]$} & & & [0.331] \\
\hline \multirow[t]{2}{*}{ Log(Audit Fees) } & $0.403 * * *$ & & & $0.394 * * *$ \\
\hline & {$[3.432]$} & & & {$[3.062]$} \\
\hline \multirow[t]{2}{*}{ Crisis*Specialist } & & -0.025 & & -0.015 \\
\hline & & {$[-0.086]$} & & {$[-0.050]$} \\
\hline \multirow[t]{2}{*}{ Specialist } & & $0.368 * *$ & & 0.282 \\
\hline & & {$[2.0136]$} & & {$[1.525]$} \\
\hline \multirow[t]{2}{*}{ Crisis*Big 4 Auditor } & & & 0.001 & 0.049 \\
\hline & & & {$[0.003]$} & {$[0.095]$} \\
\hline \multirow[t]{2}{*}{ Big 4 Auditor } & & & 0.154 & -0.264 \\
\hline & & & [0.519] & {$[-0.795]$} \\
\hline \multirow[t]{2}{*}{ Bid-Ask Spread } & $-70.079 * * *$ & $-85.004 * * *$ & $-83.845 * * *$ & $-73.322 * * *$ \\
\hline & {$[-5.760]$} & {$[-7.523]$} & {$[-6.582]$} & {$[-5.750]$} \\
\hline \multirow[t]{2}{*}{ Log(Intan. Assets) } & $0.082 *$ & $0.111 * *$ & $0.110 * *$ & $0.083^{*}$ \\
\hline & [1.868] & [2.521] & [2.512] & {$[1.876]$} \\
\hline \multirow[t]{2}{*}{ Book-To-Market } & $0.066^{* * *}$ & $0.061 * * *$ & $0.058 * * *$ & $0.068 * * *$ \\
\hline & {$[3.334]$} & [3.265] & [3.177] & [3.395] \\
\hline \multirow[t]{2}{*}{ Return On Assets } & -0.533 & -0.757 & -0.697 & -0.613 \\
\hline & {$[-0.507]$} & {$[-0.710]$} & {$[-0.668]$} & {$[-0.569]$} \\
\hline \multirow[t]{2}{*}{ Leverage } & -0.341 & -0.098 & -0.084 & -0.325 \\
\hline & {$[-0.776]$} & {$[-0.225]$} & {$[-0.190]$} & {$[-0.734]$} \\
\hline Initial Auditor Year & 0.054 & 0.036 & 0.038 & 0.036 \\
\hline
\end{tabular}




\begin{tabular}{|c|c|c|c|c|}
\hline & [0.307] & {$[0.205]$} & {$[0.214]$} & {$[0.204]$} \\
\hline \multirow[t]{2}{*}{ Log(Other Fees) } & $0.050 * *$ & $0.066^{* * *}$ & $0.071 * * *$ & $0.047 *$ \\
\hline & [1.993] & {$[2.783]$} & [2.935] & [1.904] \\
\hline \multirow{2}{*}{ Log(Properties) } & $0.208 * * *$ & $0.207 * * *$ & $0.233 * * *$ & $0.190 * * *$ \\
\hline & [4.014] & {$[3.885]$} & [4.417] & [3.625] \\
\hline \multirow[t]{2}{*}{ Log(Subsidiaries) } & $0.105^{*}$ & $0.192 * * *$ & $0.171 * * *$ & $0.124 * *$ \\
\hline & {$[1.753]$} & {$[3.441]$} & [3.024] & {$[2.080]$} \\
\hline \multirow[t]{2}{*}{ Foreign Operations } & -0.708 & -0.437 & -0.355 & -0.764 \\
\hline & {$[-1.333]$} & {$[-0.798]$} & {$[-0.666]$} & {$[-1.398]$} \\
\hline \multirow[t]{2}{*}{ Extra/Disc Items } & -0.011 & 0.064 & 0.043 & 0.011 \\
\hline & {$[-0.076]$} & {$[0.456]$} & {$[0.301]$} & {$[0.081]$} \\
\hline \multirow[t]{2}{*}{ Constant } & -1.803 & $2.472 * * *$ & $2.485^{* * *}$ & -1.574 \\
\hline & {$[-1.300]$} & {$[4.784]$} & [4.261] & {$[-1.113]$} \\
\hline \# Observations & 953 & 953 & 953 & 953 \\
\hline $\mathrm{F}$ & 17.221 & 15.887 & 16.217 & 15.737 \\
\hline Adjusted R2 & 0.261 & 0.254 & 0.250 & 0.261 \\
\hline \multicolumn{5}{|c|}{$\begin{array}{l}\text { Notes: In all models, the dependent variable is } \log \text { (Equity Investment). In Model } 4 \mathrm{a} \text {, Crisis } \\
\text { and Crisis }{ }^{*} \log \text { (Audit Fees) are added to examine the impact of audit fees on post-crisis } \\
\text { equity investment. In Model } 4 \mathrm{~b} \text {, Crisis and Crisis }{ }^{*} \text { Specialist are added to examine the impact } \\
\text { of auditor specialization on post-crisis equity investment. In Model } 4 \mathrm{c} \text {, Crisis and Crisis*Big } \\
4 \text { Auditor are added to examine the impact of auditor reputation on post-crisis equity } \\
\text { investment. In Model } 4 \mathrm{~d} \text {, Crisis and all three interaction terms are included to examine the } \\
\text { impact of the audit-related attributes of auditor quality, specialization, and reputation on } \\
\text { post-crisis equity investment. Bid-Ask Spread is an often-used measure to capture } \\
\text { transparency. Log(Intan. Assets) captures firm's level of information asymmetry or } \\
\text { opacity.Book-To-Market, Return on Assets, and Leverage capture individual REIT firm } \\
\text { characteristics.Initial and Log(Other Fees) are used to capture individual REIT-auditor } \\
\text { relationships. } \log (\text { Properties), } \log (\text { Subsidiaries), Foreign, and Extra/Disc Items capture firm } \\
\text { complexity. REIT Type and Year Dummies not reported. Regression estimations are robust } \\
\text { and statistical significance shown as: } * \text { p }<0.05, * * \text { p }<0.01, * * * p<0.001 \text {, respectively. }\end{array}$} \\
\hline
\end{tabular}

Table 10 below shows the results for testing Hypothesis 2(b) that the financial crisis positively influenced the relationship between the audit process and debt investment in REITs. Only in Model 5c is the Crisis dummy coefficient is positive and significant ( $\beta=0.552)$. This suggests that REITs relied more heavily on debt capital after the crisis than before it. Additionally, the coefficient for the interaction term Crisis*Big 4 Auditor is negative and significant $(\beta=-0.544)$. This suggests that even though REITs relied more heavily on debt 
capital after the crisis than before it, auditor reputation was of less importance. There is no statistical significance for the interactive terms for Crisis*Specialist and Crisis*Big4 Auditor.

Table 10. Results of OLS Regression testing the expectation that the financial crisis of 2007-2008 positively influenced the relationship between audit-related attributes and debt investment in REITs

\begin{tabular}{|c|c|c|c|c|}
\hline \multirow{3}{*}{ Variable } & Model 5a & Model 5b & Model 5c & Model 5d \\
\hline & Coefficient & Coefficient & Coefficient & Coefficient \\
\hline & [t-Statistic] & [t-Statistic] & [t-Statistic $]$ & [t-Statistic] \\
\hline \multirow[t]{2}{*}{ Crisis } & 0.084 & -0.086 & $0.552 * *$ & -0.109 \\
\hline & {$[0.070]$} & {$[-0.489]$} & {$[2.200]$} & {$[-0.079]$} \\
\hline \multirow[t]{2}{*}{ Crisis*Audit Fees } & -0.052 & & & -0.018 \\
\hline & {$[-0.581]$} & & & {$[-0.162]$} \\
\hline \multirow[t]{2}{*}{ Log(Audit Fees) } & $0.711 * * *$ & & & $0.679 * * *$ \\
\hline & {$[10.767]$} & & & [9.302] \\
\hline \multirow[t]{2}{*}{ Crisis*Specialist } & & 0.099 & & 0.197 \\
\hline & & [0.712] & & [1.469] \\
\hline \multirow[t]{2}{*}{ Specialist } & & $0.327 * * *$ & & $0.140^{*}$ \\
\hline & & [3.851] & & [1.748] \\
\hline \multirow[t]{2}{*}{ Crisis*Big 4 Auditor } & & & $-0.544 * * *$ & -0.341 \\
\hline & & & {$[-2.880]$} & {$[-1.480]$} \\
\hline \multirow[t]{2}{*}{ Big 4 Auditor } & & & $0.745 * * *$ & 0.077 \\
\hline & & & [4.945] & {$[0.496]$} \\
\hline \multirow[t]{2}{*}{ Bid-Ask Spread } & $-46.561 * * *$ & $-69.823 * * *$ & $-64.600 * * *$ & $-48.270 * * *$ \\
\hline & {$[-6.944]$} & {$[-9.182]$} & {$[-8.667]$} & {$[-7.190]$} \\
\hline \multirow[t]{2}{*}{ Log(Intan. Assets) } & 0.028 & $0.072 * * *$ & $0.074 * * *$ & 0.028 \\
\hline & {$[1.280]$} & [3.214] & {$[3.227]$} & {$[1.266]$} \\
\hline \multirow[t]{2}{*}{ Book-To-Market } & $0.070 * * *$ & $0.065 * * *$ & $0.059 * * *$ & $0.074 * * *$ \\
\hline & [4.353] & [4.613] & [4.335] & {$[4.585]$} \\
\hline \multirow[t]{2}{*}{ Return On Assets } & 0.769 & 0.304 & 0.461 & 0.666 \\
\hline & [1.584] & {$[0.597]$} & [0.914] & [1.358] \\
\hline Leverage & $3.954 * * *$ & $4.368 * * *$ & $4.333 * * *$ & $3.980 * * *$ \\
\hline
\end{tabular}




\begin{tabular}{|c|c|c|c|c|}
\hline & {$[13.562]$} & {$[14.014]$} & [13.672] & [13.693] \\
\hline \multirow[t]{2}{*}{ Initial Auditor Year } & 0.083 & 0.036 & 0.086 & 0.088 \\
\hline & {$[1.121]$} & {$[0.444]$} & {$[1.031]$} & [1.158] \\
\hline \multirow[t]{2}{*}{ Log(Other Fees) } & 0.002 & $0.032 * * *$ & $0.035 * * *$ & 0.001 \\
\hline & {$[0.263]$} & [3.562] & {$[3.731]$} & {$[0.0570]$} \\
\hline \multirow[t]{2}{*}{ Log(Properties) } & $0.252 * * *$ & $0.267 * * *$ & $0.289 * * *$ & $0.238 * * *$ \\
\hline & {$[5.600]$} & [5.669] & {$[6.214]$} & {$[5.273]$} \\
\hline \multirow[t]{2}{*}{ Log(Subsidiaries) } & $0.065 * *$ & $0.194 * * *$ & $0.169 * * *$ & $0.081 * *$ \\
\hline & {$[2.067]$} & {$[5.660]$} & [4.894] & {$[2.537]$} \\
\hline \multirow[t]{2}{*}{ Foreign Operations } & -0.307 & 0.184 & 0.244 & -0.354 \\
\hline & {$[-1.204]$} & {$[0.612]$} & {$[0.908]$} & {$[-1.290]$} \\
\hline \multirow[t]{2}{*}{ Extra/Disc Items } & $0.177 * *$ & $0.292 * * *$ & $0.257 * * *$ & $0.191 * * *$ \\
\hline & [2.450] & [3.828] & [3.333] & {$[2.667]$} \\
\hline \multirow[t]{2}{*}{ Constant } & $-4.253 * * *$ & $3.484 * * *$ & $2.922 * * *$ & $-4.056 * * *$ \\
\hline & {$[-5.014]$} & [9.249] & [7.077] & {$[-4.773]$} \\
\hline \# Observations & 953 & 953 & 953 & 953 \\
\hline $\mathrm{F}$ & 78.253 & 58.569 & 65.637 & 78.513 \\
\hline Adjusted R2 & 0.713 & 0.670 & 0.666 & 0.716 \\
\hline
\end{tabular}

Notes: In all models, the dependent variable is $\log ($ Debt Investment). In Model 5a, Crisis and Crisis ${ }^{*} \log$ (Audit Fees) are added to examine the impact of audit fees on post-crisis equity investment. In Model 5b, Crisis and Crisis*Specialist are added to examine the impact of auditor specialization on post-crisis equity investment. In Model 5c, Crisis and Crisis ${ }^{*}$ Big 4 Auditor are added to examine the impact of auditor reputation on post-crisis equity investment. In Model 5d, Crisis and all three interaction terms are included to examine the impact of the audit-related attributes of auditor quality, specialization, and reputation on post-crisis equity investment. Bid-Ask Spread is an often-used measure to capture transparency. $\log$ (Intan. Assets) captures firm's level of information asymmetry or opacity.Book-To-Market, Return on Assets, and Leverage capture individual REIT firm characteristics.Initial and $\log ($ Other Fees) are used to capture individual REIT-auditor relationships. Log(Properties), Log(Subsidiaries), Foreign, and Extra/Disc Items capture firm complexity. REIT Type and Year Dummies not reported. Regression estimations are robust and statistical significance shown as: $* \mathrm{p}<0.05,{ }^{* *} \mathrm{p}<0.01, * * * \mathrm{p}<0.001$, respectively.

Table 11 below shows the results for testing Hypothesis 2(c) that the financial crisis positively influenced the relationship between the audit process and combined equity and debt investment in REITs. The results are similar to those found in Model 5, with a positive, 


\section{Macrothink Institute ${ }^{\mathrm{TM}}$}

significant coefficient for Crisis $(\beta=0.552)$ in Model $6 \mathrm{c}$, suggesting that REITs relied more heavily on combined equity and debt capital after the crisis than before it. Again, similar to Model 5, the Crisis*Big 4 Auditor interaction term coefficient is negative and significant in Model $6 \mathrm{c}(\beta=-0.528)$. These findings point to a heavier reliance upon combined equity and debt capital after the crisis than before it, yet at the same time, auditor reputation was of less importance. Neither of the interactive terms Crisis*Specialist and Crisis*Big4 Auditor produced significant results.

Table 11. Results of OLS Regression testing the expectation that the financial crisis of 2007-2008 positively influenced the relationship between audit-related attributes and combined equity and debt investment in REITs

\begin{tabular}{|c|c|c|c|c|}
\hline \multirow{3}{*}{ Variable } & Model 6a & Model 6b & Model 6c & Model 6d \\
\hline & Coefficient & Coefficient & Coefficient & Coefficient \\
\hline & [t-Statistic] & [t-Statistic] & [t-Statistic] & [t-Statistic] \\
\hline \multirow[t]{2}{*}{ Crisis } & -0.129 & -0.074 & $0.552 * *$ & -0.287 \\
\hline & {$[-0.107]$} & {$[-0.420]$} & {$[2.216]$} & {$[-0.207]$} \\
\hline \multirow[t]{2}{*}{ Crisis*Log(Audit Fees) } & -0.035 & & & -0.002 \\
\hline & {$[-0.392]$} & & & {$[-0.018]$} \\
\hline \multirow[t]{2}{*}{ Log(Audit Fees) } & $0.702 * * *$ & & & $0.663 * * *$ \\
\hline & {$[10.460]$} & & & [8.940] \\
\hline \multirow[t]{2}{*}{ Crisis*Specialist } & & 0.077 & & 0.168 \\
\hline & & {$[0.557]$} & & {$[1.248]$} \\
\hline \multirow[t]{2}{*}{ Specialist } & & $0.353 * * *$ & & $0.167 * *$ \\
\hline & & [4.109] & & [2.059] \\
\hline \multirow[t]{2}{*}{ Crisis*Big 4 Auditor } & & & $-0.528 * * *$ & -0.343 \\
\hline & & & {$[-2.822]$} & {$[-1.477]$} \\
\hline \multirow[t]{2}{*}{ Big 4 Auditor } & & & $0.778 * * *$ & 0.122 \\
\hline & & & {$[5.125]$} & {$[0.762]$} \\
\hline \multirow[t]{2}{*}{ Bid-Ask Spread } & $-48.698 * * *$ & $-72.003 * * *$ & $-66.020 * * *$ & $-49.864 * * *$ \\
\hline & {$[-7.210]$} & {$[-9.422]$} & {$[-8.781]$} & {$[-7.356]$} \\
\hline \multirow[t]{2}{*}{ Log(Intan. Assets) } & 0.032 & $0.077 * * *$ & $0.077 * * *$ & 0.033 \\
\hline & {$[1.465]$} & [3.401] & {$[3.402]$} & [1.489] \\
\hline Book-To-Market & $0.062 * * *$ & $0.057 * * *$ & $0.051 * * *$ & $0.065 * * *$ \\
\hline
\end{tabular}




\begin{tabular}{|c|c|c|c|c|}
\hline & {$[4.1009]$} & [4.297] & [3.925] & [4.369] \\
\hline \multirow[t]{2}{*}{ Return On Assets } & 0.503 & 0.051 & 0.216 & 0.410 \\
\hline & [0.996] & {$[0.096]$} & {$[0.417]$} & {$[0.793]$} \\
\hline \multirow[t]{2}{*}{ Leverage } & $3.474 * * *$ & $3.884 * * *$ & $3.843 * * *$ & $3.492 * * *$ \\
\hline & [11.886] & [12.472] & [12.171] & [11.974] \\
\hline \multirow[t]{2}{*}{ Initial Auditor Year } & 0.081 & 0.036 & 0.090 & 0.091 \\
\hline & [1.087] & {$[0.444]$} & [1.072] & [1.186] \\
\hline \multirow[t]{2}{*}{ Log(Other Fees) } & 0.009 & $0.038 * * *$ & $0.041 * * *$ & 0.007 \\
\hline & {$[0.892]$} & [4.103] & [4.235] & {$[0.713]$} \\
\hline \multirow[t]{2}{*}{ Log(Properties) } & $0.244 * * *$ & $0.258 * * *$ & $0.281 * * *$ & $0.230 * * *$ \\
\hline & {$[5.387]$} & {$[5.437]$} & {$[6.005]$} & {$[5.022]$} \\
\hline \multirow[t]{2}{*}{ Log(Subsidiaries) } & $0.075^{* *}$ & $0.205^{* * *}$ & $0.178^{* * *}$ & $0.092 * * *$ \\
\hline & {$[2.355]$} & {$[5.937]$} & {$[5.125]$} & {$[2.851]$} \\
\hline \multirow[t]{2}{*}{ Foreign Operations } & -0.386 & 0.099 & 0.165 & -0.430 \\
\hline & {$[-1.551]$} & {$[0.335]$} & {$[0.627]$} & {$[-1.598]$} \\
\hline \multirow[t]{2}{*}{ Extra/Disc Items } & $0.137 *$ & $0.252 * * *$ & $0.215^{* * *}$ & $0.152 * *$ \\
\hline & {$[1.880]$} & [3.285] & [2.774] & [2.095] \\
\hline \multirow[t]{2}{*}{ Constant } & $-3.788 * * *$ & $3.839 * * *$ & $3.255 * * *$ & $-3.559 * * *$ \\
\hline & {$[-4.391]$} & [10.061] & [7.829] & {$[-4.116]$} \\
\hline \# Observations & 953 & 953 & 953 & 953 \\
\hline $\mathrm{F}$ & 73.080 & 55.324 & 62.526 & 73.510 \\
\hline Adjusted R2 & 0.699 & 0.656 & 0.653 & 0.702 \\
\hline
\end{tabular}

Notes: In all models, the dependent variable is $\log$ (Equity \& Debt Investment). In Model 6a, Crisis and Crisis ${ }^{*} \log$ (Audit Fees) are added to examine the impact of audit fees on post-crisis equity investment. In Model 6b, Crisis and Crisis*Specialist are added to examine the impact of auditor specialization on post-crisis equity investment. In Model 6c, Crisis and Crisis*Big 4 Auditor are added to examine the impact of auditor reputation on post-crisis equity investment. In Model 6d, Crisis and all three interaction terms are included to examine the impact of the audit-related attributes of auditor quality, specialization, and reputation on post-crisis equity investment. Bid-Ask Spread is an often-used measure to capture transparency. Log(Intan. Assets) captures firm's level of information asymmetry or opacity.Book-To-Market, Return on Assets, and Leverage capture individual REIT firm characteristics.Initial and $\log ($ Other Fees) are used to capture individual REIT-auditor relationships. Log(Properties), Log(Subsidiaries), Foreign, and Extra/Disc Items capture firm 
complexity. REIT Type and Year Dummies not reported. Regression estimations are robust and statistical significance shown as: ${ }^{*} \mathrm{p}<0.05,{ }^{* *} \mathrm{p}<0.01$, ${ }^{* * *} \mathrm{p}<0.001$, respectively.

Many of the control variables provide interesting results. For example, Bid-Ask Spread, one of the variables used to capture financial transparency, is also negative and significant in all models. Log(Intan Assets), our proxy for information asymmetry/opacity, is largely positive and significant, which suggests that when REIT investors view REITs as more transparent (lower bid-ask spreads), or when they perceive lower levels of information asymmetry (lower levels of intangible assets), they are more inclined to invest in REITs. The number of properties owned by REITs and/or their subsidiaries contributes to their demand for capital investment. To control for this, we use the variable $\log$ (Properties). In all models, the coefficients for $\log$ (Properties) are positive and significant, revealing a positive relationship between the number of properties owned and REIT capital investment. This finding is not altogether surprising. Because REITs have to distribute the bulk of their available cash as dividends, to acquire additional properties, they need new capital. As REITs acquire more properties, and increase needs for additional capital, implementing strategies to lower information asymmetries and increase financial transparency takes on added importance. In a similar fashion, all models show positive and significant coefficients for $\log$ (Subsidiaries), another REIT complexity indicator. Logically, increased subsidiary investment and operation requires increased capital investment.

\section{Conclusion}

Existing research indicates that firms use the audit process as a means of conveying information to investors, often in attempts to signal their increased financial transparency. In this paper, we examine how REITs use the audit-related attributes of auditor quality, specialization, and reputation to signal or convey financial transparency to potential investors in order to motivate capital investment. We first analyze the relationship between these three audit-related attributes and REIT equity, debt, and combined equity and debt capital investment. We then analyze this relationship by considering the financial crisis to investigate whether the use of these audit-related attributes has a stronger impact on capital issuance after the crisis.

Studies confirm that when firms signal their increased financial transparency to investors, they improve their abilities to motivate capital investment. Empirical analysis results show a positive association between the audit process and increased capital investment before the crisis. Moreover, notwithstanding declined use of equity and debt by all REITs after the crisis, the results indicate the existence of a positive association between the audit process and increased capital investment after the crisis. This means that regardless of whether the economy is growing or contracting, using the audit process to satisfy REIT investors' concerns about financial transparency is a wise strategy. 


\section{References}

American Institute of Certified Public Accountants (AICPA). (1978). The Commission on Auditors' Responsibilities: Report, Conclusions and Recommendations. The Cohen Commission.New York: AICPA.

Abdolmohammadi, M. J., D. G. Searfoss, \& J. Shanteau. (2004). An Investigation of the Attributes of Top Industry Audit Specialists. Behavioral Research in Accounting, 16(1), 1-17. https://doi.org/10.2308/bria.2004.16.1.1

Antle, R., E. Gordon, G. Narayanamoorthy, \& L. Zhou. (2006). The Joint Determination of Audit Fees, Non-audit Fees, and Abnormal Accruals. Review of Quantitative Finance and Accounting, 27(3), 235-266. https://doi.org/10.1007/s11156-006-9430-y

Bagehot, W. (1971). The Only Game in Town.Financial Analysts Journal, 51(1), 12-14. https://doi.org/10.2469/faj.v27.n2.12

Balvers, R. J., B. McDonald, \& R. E. Miller. (1988). Underpricing of New Issues and the Choice of Auditor as a Signal of Investment Banker Reputation. The Accounting Review, 63(4), 605-622.

Basse, T., M. Friedrich, \& E. V. Bea. (2009). REITs and the Financial Crisis: Empirical Evidence from the U.S. International Journal of Business and Management, 4(11), 1-10. https://doi.org/10.5539/ijbm.v4n11p3

Beatty, R. P. (1989).Auditor Reputation and the Pricing of Initial Public Offerings.The Accounting Review, 64(4), 693-709.

Bell, T., F. Marrs, I. Solomon, and H. Thomas. (1997). Auditing Organizations through a Strategic Lens, the KPMG Business Measurement Process. Montvale, NJ: Peat Marwick LLP.

Boo, E., \& D. Sharma. (2008). Effect of Regulatory Oversight on the Association between Internal Governance Characteristics and Audit Fees.Accounting and Finance, 48(1), 51-71. https://doi.org/10.1111/j.1467-629X.2007.00229.x

Bushman, R. M., \& A. J. Smith.(2001). Financial Accounting Information and Corporate Governance.Journal of Accounting and Economics, 32(1-3), 237-333.

Bushman R. M., \& A. J. Smith. (2003). Transparency, Financial Accounting Information and Corporate Governance.Federal Reserve Bank of New York's Economic Policy Review, 9(1), 65-87. https://doi.org/10.1016/S0165-4101(01)00027-1

Campbell, J. Y., \& R. J. Shiller. (1988). The Dividend-Price Ratio and Expectations of Future Dividends and Discount Factors. Review of Financial Studies, 1(3), 195-228. https://doi.org/10.1093/rfs/1.3.195

Carter, R. B., \& S. Manaster.(1990). Initial Public Offerings and Underwriter Reputation.The Journal of Finance, 45(4), 1045-1067. https://doi.org/10.1111/j.1540-6261.1990.tb02426.x

Chan, P., M. Ezzamel, \& D. Gwilliam. (1993). Determinants of Audit Fees for Quoted U.K. 
Companies. Journal of Business. Finance and Accounting, 20(6), 765-786.

Chen, C. R., \& T. L. Steiner. (1999). Managerial Ownership and Agency Conflicts: A Nonlinear Simultaneous Equation Analysis of Managerial Ownership, Risk Taking, Debt Policy, and Dividend Policy. Financial Review, 34(1), 119-136. https://doi.org/10.1111/j.1540-6288.1999.tb00448.x

Cohen, J., G. Krishnamoorthy, \& A. M. Wright.(2002). Corporate Governance and Audit Process.Contemporary Accounting Research, 19(4), 573-594.

Cornett, M. M., A. J. Marcus, \& H. Tehranian. (2008). Corporate Governance and Pay-for-Performance: The impact of Earnings Management. Journal of Financial Economics, $87(2), 357-373$.

Danielsen, B. R., D. M. Harrison, R. A. Van Ness, \& R. S. Warr.(2009). REIT Auditor Fees and Financial Market Transparency. Real Estate Economics, 37(3), 515-557.

Danielsen, B. R., D. M. Harrison, R. A. Van Ness, \& R. S. Warr. (2014). Liquidity, Accounting Transparency, and the Cost of Capital: Evidence from Real Estate Investment Trusts. Journal of Real Estate Research, 36(3), 221-251.

Danielsen, B. R., R. A. Van Ness, and R. S. Warr.(2007). Auditor Fees, Market Microstructure, and Firm Transparency.Journal of Business Finance \& Accounting, 34(1-2), 202-221.

Datar, S., G. Feltham, \& J. Hughes. (1991). The Role of Audits and Audit Quality in Valuing New Issues. Journal of Accounting and Economics, 14(1), 3-49.

DeAngelo, L. E. (1981). Auditor Size and Quality. Journal of Accounting and Economics, 3(3), 183-199.

Deeds, D. L., D. Decarolis, \& J. E. Coombs. (1997). The Impact of Firm-Specific Capabilities on the Amount of Capital Raised in an Initial Public Offering: Evidence from the Biotechnology Industry. Journal of Business Venturing, 12(1), 31-46.

DeLisle, J. R. (2007). At the Crossroads of Expansion and Recession. The Appraisal Journal, 75(4), 314-322.

DeLisle, J. R. (2008). The Perfect Storm Rippling Over to Real Estate. The Appraisal Journal, 76(3), 200-210.

Demsetz, H. (1968). The Cost of Transacting. Quarterly Journal of Economics, 82(1), 33-53.

Diamond, D. W., \& R. E. Verrecchia. (1991). Disclosure, Liquidity, and the Cost of Capital. The Journal of Finance, 46(4), 1325-1359.

Fama, E. F., \& M. C. Jensen.(1983). Separation of Ownership and Control. Journal of Law and Economics, 26(June), 301-325.

Feltham, G. A., J. S. Hughes, \& D. A. Simunic. (1991). Empirical Assessment of the Impact of Auditor Quality on the Valuation of New Issues. Journal of Accounting and Economics, 14(4), 375-399. 
Firth, M., \& A. Smith. (1992). Selection of Auditor Firms by Companies in the New Issue Market. Applied Economics, 24(2), 247-255.

Francis, J., T. Lys, \& L. Vincent, L. (2004). Valuation Effects of Debt and Equity Offerings by Real estate Investment Trusts. (Working Paper). Duke University and Northwestern University. Retrieved on April 23, 2012, from http://www.kellogg.northwestern.edu/faculty/vincentl/htm/offerings.pdf.

Friday, S. W., \& S. G. Sirmans. (1998). Board of Director Monitoring and Firm Value in REITs. Journal of Real Estate Research, 16(3), 411-428.

Geiger, M. A., \& K. Raghunandan. (2002). Auditor Tenure and Audit Reporting Failures. AUDITING: A Journal of Practice and Theory, 21(1), 67-78.

Goebel, P. R., \& K. S. Kim. (1989). Performance Evaluation of Finite-Life Real Estate Investment Trusts. Journal of Real Estate Research, 4(2), 57-69.

Goodman, G. A. (2000). German Investment in U.S. Real Estate: The Acceleration Continues. Real Estate Review, 30(1), 1-20.

Goodman, G. A. (2003). Homeownership and Investment in Real Estate Stocks. Journal of Real Estate Portfolio Management, 9(2): 93-105.

Hair, J. F., Jr., W. C. Black, B. J. Babin, \& R. E. Anderson. (2002). Multivariate Data Analysis (7th Ed). Upper Saddle River, NJ: Prentice-Hall.

Hardin, W. G., \& Z. Wu. (2010). Banking Relationships and REIT Capital Structure.Real Estate Economics, 38(2), 257-284.

Hay, D., and D. Davis. (2004). The Voluntary Choice of an Audit of Any Level of Quality. AUDITING: A Journal of Practice \& Theory, 23(2), 37-53.

Healy, P. M., \& K. G. Palepu. (2001). Information Asymmetry, Corporate Disclosure, and the Capital Markets: A Review of the Empirical Disclosure Literature. Journal of Accounting and Economics, 31(1-3), 405-440.

Higgs, J. L., and T. R. Skantz.(2006). Audit and Nonaudit Fees and the Market's Reaction to Earnings Announcements. AUDITING: A Journal of Practice Theory, 25(1), 1-26.

Hope, O. K., W. B. Thomas, \& D. Vyas. (2009). Transparency, Ownership, and Financing Constraints in Private Firms.(Working Paper).Canada: University of Toronto.Retrieved on October 30, 2012, from http://www2.accountancy.smu.edu.sg/research/seminar/pdf/OleKristianHOPE_paper.pdf.

Johnson, V. E., I. K. Khurana, \& J. K. Reynolds. (2002). Audit-Firm Tenure and the Quality of Financial Reports. Contemporary Accounting Research, 19(4), 637-660.

Karamanou, I., \& N. Vafeas. (2005). The Association Between Corporate Boards, Audit Committees, and Management Earnings Forecasts: An Empirical Analysis. Journal of Accounting Research, 43(3), 453-486. 
Knechel, W. R., \& D. S. Sharma. (2012). Auditor-provided nonaudit services and audit effectiveness and efficiency: Evidence from pre-and post-SOX audit report logs. AUDITING: A Journal of Practice \& Theory, 31(4), 85-114.

Mansi, S. A., W. F. Maxwell, \& D. P. Miller. (2004). Does auditor quality and tenure matter to investors? Evidence from the bond market. Journal of Accounting Research, 42(4), 755-793.

Myers, S. C. (1984). The capital structure puzzle. The Journal of Finance, 39(3), 574-592.

Myers, J. N., L. A. Myers, \& T. C. Omer. (2003). Exploring the term of the auditor-client relationship and the quality of earnings, a case for mandatory auditor rotation. The Accounting Review, 78(3), 779-799.

Naiker, V., D. S. Sharma, \& V. D. Sharma. (2013). Do former audit firm partners on audit committees procure greater nonaudit services from the auditor? The Accounting Review, 88(1), 297-326.

National Association of Real Estate Investment Trusts. (2012). Retrieved on May 4, 2012, from: http:www/reit.com.

Peel, M. J., \& R. Roberts. (2003). Audit fee determinants and auditor premiums: Evidence from the micro-firm sub-market. Accounting and Business Research, 33(3), 207-233.

Ritter, J. R. (1984). Signaling and the valuation of unseasoned new issues: A comment. The Journal of Finance, 39(4), 1231-1237.

Scherrer, P. S. (2004). Financing and investing considerations for REITs. Corporate Governance, 4(4), 78-82.

Simunic, D., \& M. Stein. (1987). Production differentiation in auditing: A study of auditor choice in the market for new issues. (Canadian Certified General Accountant's Research Foundation, Research Report).Retrieved on May 8, 2012, from http://scholar.google.com/scholar?cites $=6579729753907499239 \& a s \_s d t=205 \&$ sciodt $=0,1 \&$ hl $=$ en.

Solomon, I., M. Shields, \& R. Whittington. (1999). What do industry-specialist auditors know? Journal of Accounting Research, 37(1), 191-208.

Spence, M. (1973). Job market signaling.Quarterly Journal of Economics, 87(3), 355-374.

Titman, S., \& B. Trueman. (1986). Information quality and the valuation of new issues. Journal of Accounting and Economics, 8(2), 159-172.

Watts, R. L., \& J. L. Zimmerman. (1983). Agency problems, auditing, and the theory of the firm: Some evidence. Journal of Law and Economics, 26(3), 613-633.

\section{Notes}

Note 1. From 1976-2011, the average annual return of the FTSE-NAREIT All-REIT Index was $12.98 \%$. Over the same period, the average annual returns of the S\&P 500 Index, the Dow Jones Industrial Average, and the NASDAQ Composite Index were 10.57\%, 7.40\%, and 
$9.83 \%$, respectively. Data obtained from NAREIT, available at www.reit.com.

Note 2. The average annual returns of the FTSE-NAREIT All-REIT Index in the years 2009, 2010 , and 2011 , were $27.45 \%, 27.58 \%$, and $7.28 \%$, respectively. The average annual returns of the S\&P 500 Index in the years 2009, 2010, and 2011, were $23.45 \%, 12.78 \%$, and $0.01 \%$, respectively. The average annual returns of the Dow Jones Industrial Average in the years 2009,2010 , and 2011 , were $18.82 \%, 11.02 \%$, and $5.53 \%$, respectively. The average annual historical returns of the NASDAQ Composite Index in the years 2009, 2010, and 2011, were $43.89 \%, 16.91 \%$, and $-1.80 \%$, respectively. Data obtained from NAREIT, available at www.reit.com.

Note 3. REITs must annually elect REIT status, and disclose their election in their annual proxy statement. Data available at http://www.sec.gov.

Note 4. Data available at http://www.sec.gov.

Note 5. Data obtained by licensed access to the University of Pennsylvania's Wharton Research Data Services, available at http://wrds-web.wharton.upenn.edu/wrds/index.cfm.

Note 6. Audit fee information comes from the Audit Analytics database.

Note 7. So as not to lose zero value observations when log transforming variables, researchers commonly compute the natural $\log$ of the sum of the variable and one (for examples, see Campbell \& Shiller, 1988; Chen \& Steiner, 1999; Cornett, Marcus, \& Tehranian, 2008; Ritter, 1984). Throughout this paper, we follow this approach when log transforming variables.

Note 8. For the purposes of this research, auditor specialization includes auditors that performed $30 \%$ or more of all REIT audits in the sample. Table 4 groups all REIT audits by audit firm, total audit fees, and average audit fees. Of the 980 total REIT audits performed in the sample, Ernst \& Young, LLP performed 327, or 33.37\%. All other auditors each performed less than $18 \%$ of the total number of REIT audits in the sample. Auditor rank order is by percentage of REIT audits performed.

Note 9. The group of audit firms currently known as the "Big 4" includes Price Waterhouse Coopers, LLP, Deloitte \& Touche, LLP, Ernst \& Young, LLP and KPMG, LLP ranked 1 through 4 based on annual revenues, respectively (www.Big4.com, 2012).

Note 10. Ibid, Footnote 7.

Note 11. Ibid, Footnote 7.

Note 12. Ibid, Footnote 7.

Note 13. Ibid, Footnote 7.

\section{Copyright Disclaimer}

Copyright for this article is retained by the author(s), with first publication rights granted to the journal.

This is an open-access article distributed under the terms and conditions of the Creative Commons Attribution license (http://creativecommons.org/licenses/by/3.0/). 